\title{
Does Cereal crops asymmetrically affect Agriculture gross domestic product in Pakistan? Using NARDL model approach
}

\author{
Imad $\mathrm{Ali}^{1}$ (D) Imran Khan ${ }^{1}{\text { Hashmat } \text { Ali }^{2} \text { Khan } \text { Baz }^{3} \text { Qiangqiang Zhang }}^{1}$ (D) \\ Ajab Khan ${ }^{2}$ Xuexi Huo ${ }^{*}$
}

${ }^{1}$ College of Economics and management, Northwest A\&F UniversityYangling, Shaanxi, 712100, China.

E-mail: xuexihuo@nwsuaf.edu.cn. "Corresponding author.

${ }^{2}$ Abbottabad University of Science and Technology, Havelian, Khyber Pahktunkhwa, Pakistan.

${ }^{3}$ School of Economics and Management, China University of Geosciences, Wuhan, Hubei, China.

ABSTRACT: This study contributes to the extant literature on the nexus among rice, maize and wheat production with agriculture gross domestic product (AGDP) of Pakistan. We use time series data from 1970 to 2017 and employ the Non-linear Autoregressive Distributed Lag (NARDL) model. Short run and long run shocks between the selected variables and result's is checked through the co-integration and nonlinear error correction model.Autoregressive distributed lag bound testing approach for co-integration and to find the relationship between variables Granger causality test is applied.Our results confirm co-integration, positive shocks results show that rice, maize and wheat production have significantly influence on AGDP. The asymmetrically positive shocks of three crops have neutral effect on AGDP. While in symmetric results show the unidirectional effect between rice, maize production with AGDP and wheat production do not have ganger causality with AGDP. Finally, results depict that wheat, maize and rice production significantly contributes to agricultural GDP in the case of Pakistan. Key words: NARDL model, asymmetric causality, symmetric causality, cereal crops, Pakistan AGDP.

As colheitas de cereais afetam assimetricamente o produto interno bruto da agricultura no Paquistão? Usando a abordagem do modelo NARDL

RESUMO: Este estudo contribui para a literatura existente sobre o nexo entre a produção de arroz, milho e trigo com produto interno bruto agrícola (AGDP) do Paquistão. Utilizamos dados de séries temporais de 1970 a 2017 e empregamos o modelo NARDL (Non-linear Autoregressive Distributed Lag). Choques de curto e longo prazo entre as variáveis selecionadas e os resultados são verificados por meio do modelo de co-integração e correção não linear de erros. É aplicada uma abordagem de teste de atraso retardado distribuido autorregressivo para co-integração e para encontrar a relação entre variáveis. Nossos resultados confirmam a co-integração; os resultados de choques positivos mostram que a produção de arroz, milho e trigo influencia significativamente na AGDP. Os choques assimétricos positivos de três culturas têm efeito neutro no AGDP. Enquanto nos resultados simétricos mostram o efeito unidirecional entre o arroz, a produção de milho com AGDP e a produção de trigo não têm causalidade de ganger com AGDP. Finalmente, os resultados mostram que a produção de trigo, milho e arroz contribui significativamente para o PIB agrícola no caso do Paquistão.

Palavras-chave: modelo NARDL, causalidade assimétrica, causalidade simétrica, PIB do Paquistão, produção de três culturas.

\section{INTRODUCTION}

Countries agriculture sectors and other sectors all together plays essential role in socio economic development and economic growth (IOHNSTON et al.,1970; SINGH et al., 2016).. Pakistan's agriculture sector is very important pillar for national economy because it controls food insecurity regarding to the increasing of country's population (GOP, 2018). Since Pakistan came into being national economy was based on agriculture further economy is diversified due to industrialization. Due to the industrialization in country and agriculture share is decrease in gross domestic product but the agriculture importance cannot be ignored (RAZA ALI et al., 2012). Mostly Pakistan population is living in rural areas and their income is connected with agriculture. This is providing $42.3 \%$ share of employment and as well as put some effort in poverty alleviation (ATIF HAIYUN et al., 2017). Agriculture 
sector share is $19.8 \%$ in gross domestic product and highest growth is $3.5 \%$ in 2017 after six years while it is remarkable of achievement of all sectors in the country economy with an increase growth rate(GOP, 2018).Pakistan's agriculture sector is comprised on fisheries, livestock, forestry and crops. However, wheat, maize and rice are the main three cereal crops which are grown in country.

The suitable weather condition and wellarranged irrigation system is cause that the high yield of Maize, Rice and wheat production in Pakistan. It is concluded that the weather and temperature condition is suitable and positive influence the major crop production in Pakistan (ALI et al., 2017). Our country important crops are Maize, Sugarcane, Rice, Cotton and wheat which have $23.60 \%$ and $5.45 \%$ shares respectively in the agriculture GDP and total country GDP. However, by the adaptation of modern technologies and new methods farmers can be selfsufficient in food products (GOP, 2018). Cereal crops of Pakistan have huge share in export and direct contribution to GDP. The total annual export for the 2017 year of Rice, Maize and Wheat are 3947365, 55282 and 5091 Tons respectively (FAO, 2018a). There is a big importance of food crops in agriculture sector as well as for human diet. The food crops having a much source of mineral, fats, vitamins and protein while with use of cereal crops it help to prevent the body from gaining weight and diseases of heart (SARWAR et al., 2013). The reason behind the high demand of food crops are increasing in population and their automatically eating consumption in Pakistan.

Globally, Maize is cultivated very extensively and it is considered prime and staple good.

The total maize production is about 875 , 226,630 ton in which America, China and Brazil at the top (RANUM et al., 2014). Maize crops is considering miracle cereal crop due to high potential energy is called queen of cereal. The Maize is used in Pakistan for multi purposes such as food security, poultry fed, forage and as well as used in industries as a raw material. Generally, in Pakistan this crop cultivated by the small farmers in their marginal land.

Usually, the small household farmers use their marginal land for maize crops cultivation. It reported that maize is cultivated on 1,348 and 1,229 thousand hectare area for the year 2016 and 2017, and which show decrease in $8.8 \%$ thousand hectare area. Due to the decrease in the cultivation of land automatically production is decline $7.0 \%$, while the total production is 5702 million tons for the year 2017-18 (GOP, 2108). The reason behind the low production the famers switch over maize cultivation while persuade to cotton, rice and sugarcane. Maize gained $2.4 \%$ share and 0.5 share in the total agriculture GDP and total country GDP respectively (GOP, 2017). Maize production has positive effect the economic growth of Zimbabwe in the long run and short run (MAPFUMO A, 2013).

Rice plays an important role in agriculture sector and our country economy, while in the different parts of Pakistan rice is grown such as north, west and south part. Rice is globally important trade commodity and it is also considered a staple food for the population (HUSSAIN, 2012; SECK DIANGNI et al., 2012). The rice food is providing nutrition and also controlling the food insecurity problem in Pakistan. National and international level markets the Pakistani rice is very famous due to their softness. Pakistan has $10^{\text {th }}$ position in producers countries while $4^{\text {th }}$ position in exporting countries of Rice (FAO, 2018b). The rice is cultivated on area 2899 thousand hectare however the production is 7442 million tons. The share of rice in country agriculture GPD $3.1 \%$ and $0.6 \%$ share in total GDP (FAO, 2018a). Empirical analysis shows that rice crop has positive effect on trade and gross domestic product of India and Bangladesh (DOROSH, 2004).

In Pakistan wheat crop is very important crop because $80 \%$ farmers are cultivating in "Rabi" season while wheat has captured $40 \%$ area of total cultivated land. This crop is the second is second largest crop in Pakistan. Wheat is also a staple food and providing energy and protein to eating bodies. In our county one body's wheat flour per year consumption is $124 \mathrm{~kg}$ and provides $72 \%$ calorie on daily bases (USDA, 2017). In the year 2017-18 wheat is cultivated on land area 8734 thousand hectare and the production is 25492 thousand tons. In agriculture GDP the wheat share is $9.1 \%$ while in the total GDP share is $1.7 \%$ (GOP, 2017). It is empirically checked in time series data that Pakistan major crops such as: rice, wheat, cotton and rice have positive effect on economic growth (RAZA, 2012).

\section{OBJECTIVES OF RESEARCH}

The study of (ARIF ULLAH et al,. 2018) tested long term-run relationship between agriculture gross domestic product and fruits production of Pakistan in which results shows had positive impact on agriculture gross domestic product of Pakistan .This paper investigates the long-run relationship between agriculture GDP and the three cereal crops (wheat, maize and peach) production by the nonlinear autoregressive distributive lag (NARDL) 
model and Johansen technique for co-integration in the case of Pakistan. In this perspective, this study analyses the Bounds test to confirm the long-run existence of co-integration between agriculture GDP and the three selected crops outputs. The objective are given: a) Do positive and negative shocks of cereal crops in long run and short run have influence the on agriculture gross domestic product? b) Do positive and negative shocks of cereal crops in long run and short run symmetrically and asymmetrically have granger causality with agriculture gross domestic product? c) Do cereal crops have bidirectional, unidirectional impact on Pakistan agriculture gross domestic product? These objective answer is find out with the help of co-integration techniques and nonlinear autoregressive distrusted lag.

This study investigates the relationship between three cereal crops production of Pakistan included Maize, Rice and Wheat with Agriculture Gross Domestic Product. Pakistan agriculture sector is playing a key in the country's economy development. This research find out the impact of cereal crops on agriculture value added GDP. The relationship between the variables are short run and long run in the presence of asymmetric and symmetric causality. The remaining paper is organized as follow: in section 2 data materials and methodology and the 3 section represents the results and their discussion. In the last section conclusion and recommendations are included.

\section{DATA MATERIALS}

The time series data is used in this research to check the asymmetric and symmetric causal relationship between AGDP and three crops are selected (rice, maize and wheat) of Pakistan. Figure 1, 2 and 3 show the independent variables are rice, maize and wheat production in thousand tons and dependent variable is AGDP which are present in US $\$$ in millions. Annually data was used and this data covering the time period for 1970 to 2017 . These three cereal crops data are selected from economic survey of Pakistan and food agriculture organization (FAO, 2018a; GOP, 2018) and while the agriculture gross domestic product data taken from world development bank indicator (WDI, 20118).

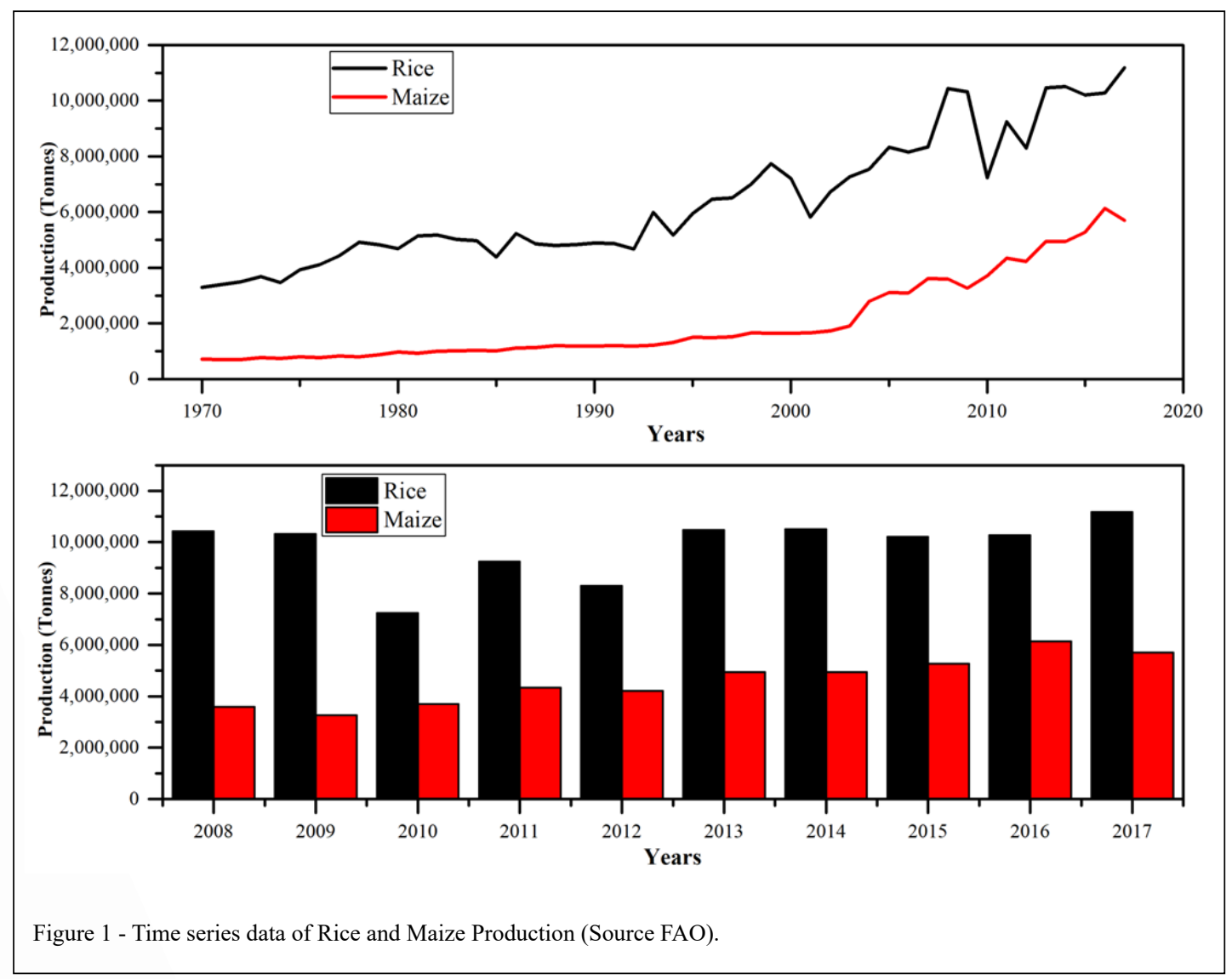

Ciência Rural, v.50, n.5, 2020. 


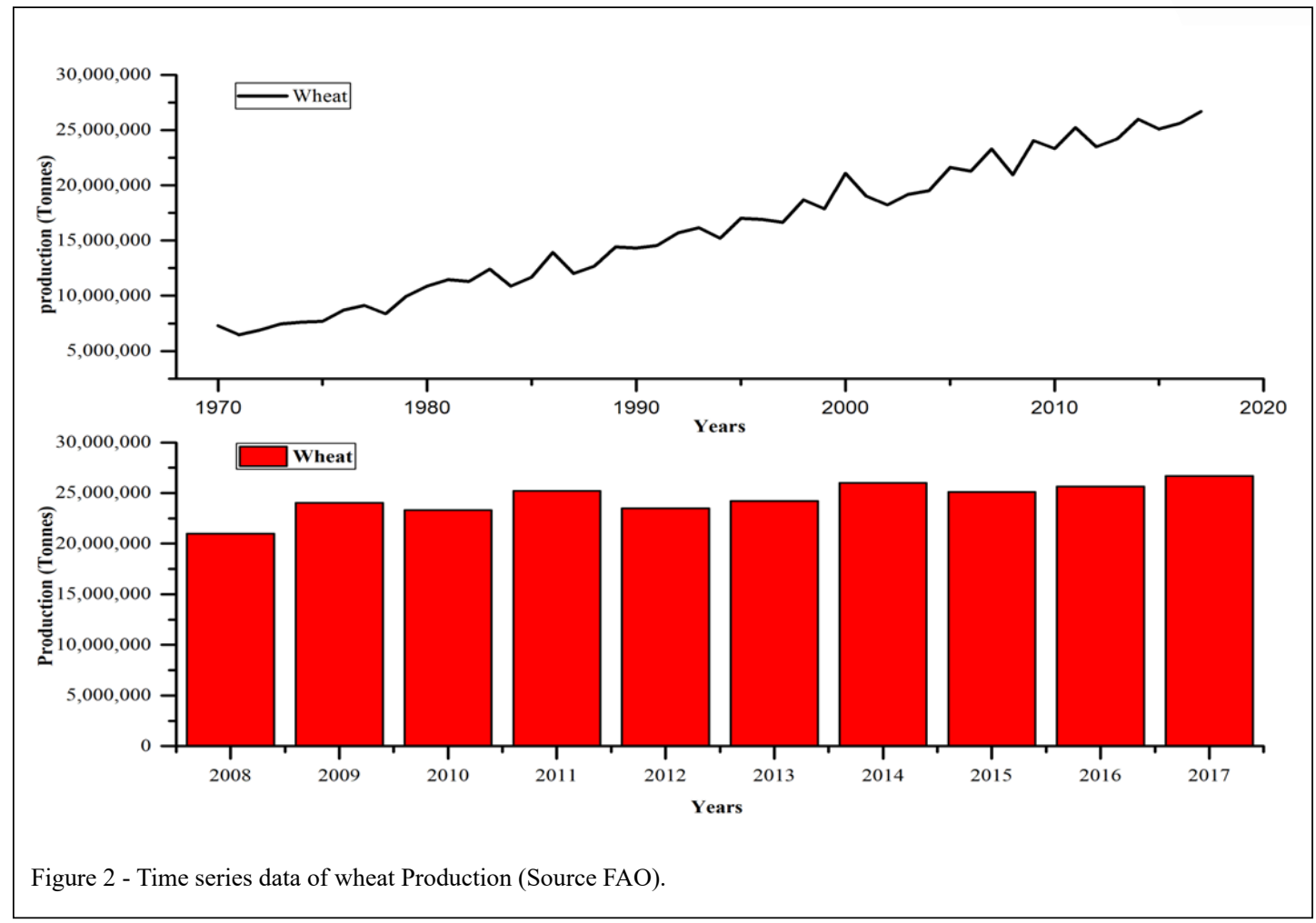

\section{METHODOLOGY}

This study investigates the relationship between three cereal crops production of Pakistan included Maize, Rice and Wheat with Agriculture Gross Domestic Product by employing nonlinear autoregressive regressive distributed model (NARDL) as well as Johansen test and co-integration test. Before find out the granger causality relationship for short time and longtime while, first we need to confirm the existence of stationary and co-integration test in three selected crops and AGDP.

To capture non-linear and asymmetric relationship among the variables, we applied nonlinear autoregressive distribution lag (NARDL) model developed by(HATEMI-J, 2012). NARDL model capture the nonlinear and asymmetric co-integration between variables, it is also distinguishes short-term and long-term effects of the independent variables on the dependent variable. Additionally, NARDL is most suitable instrument for time series data to test co-integration among the variables in single equation. While, linear ARDL model fail to detect these tests properly. In this model, we found long run and short run impact of independent variables on dependent variables. Recently, NARDL test proposed by (SHAHBAZ et al., 2017; SHIN, YU et al. 2014) show asymmetric error correction term as follow:

$$
\begin{aligned}
& \Delta Y_{t}=\alpha_{0}+p Y_{t-1}+\beta_{1}^{+} R_{t-1}^{+}+\beta_{2}^{-} R_{t-1}^{-}+\beta_{3}^{+} M_{t-1}^{+}+\beta_{4}^{-} M_{t-1}^{-}+\beta_{5}^{+} W_{t-1}^{+}+\beta_{6}^{-} W_{t-1}^{-}+ \\
& \sum_{i=1}^{p} \alpha_{1} \Delta Y_{t-i}+\sum_{i=0}^{r} \alpha_{2} R_{t-i}^{+}+\sum_{i=0}^{r} \alpha_{3} R_{t-i}^{-}+\sum_{i=0}^{r} \alpha_{4} M_{t-i}^{+}+\sum_{i=0}^{r} \alpha_{s} M_{t-i}^{-}+\sum_{i=0}^{r} \alpha_{6} W_{t-i}^{+}+\sum_{i=0}^{-} \alpha_{t} W_{t-i}^{-}+\mu_{t}
\end{aligned}
$$

In NARDL equation, $\alpha_{i}$ is represents short run and $\beta_{\mathrm{i}}$ is long term coefficients with $\mathrm{i}=$ 1 1...8th. While, the short term analysis is immediate effect of independent variable towards dependent variables. Where long term analysis reveal the speed of adjustment towards equilibrium. All our variables $Y_{t}, R_{t}, M_{t}$ and $W_{t}$ are represents as AGDP, rice production, maize production and wheat production, respectively, with t time. We run Wald test to know the long run asymmetry $\quad \beta=\beta^{+}=\beta^{-}$and for short run asymmetry $\alpha=\alpha^{+}=\alpha^{-}$for all selected variables.

To find the nexus among, maize, rice and wheat and AGDP we applied Granger Causality test. To capture asymmetric causality among the variables, we used same method as (HATEMI-J, 2012) for time and frequency domain method of (BREITUNG \& CANDELON, 2006). In first phase, we create positive and negative shocks for 


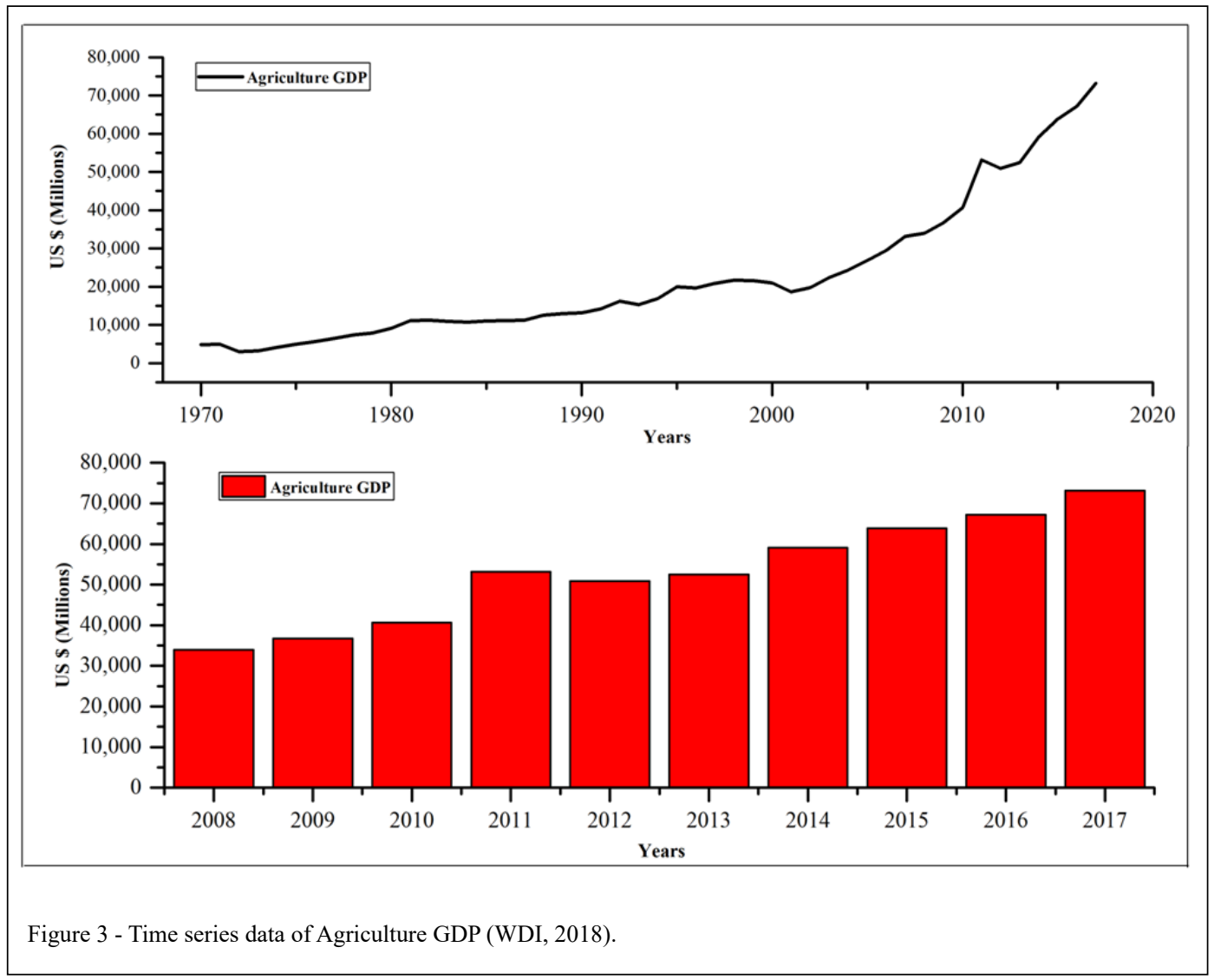

all variables and decompose these shocks via white noise error:

$X_{j, t}=X_{j, t-1}+\grave{o}_{j, t}=X_{j, 0}+\sum_{i=1}^{t} \grave{o}_{j, i}$

Each shock can be identified by analyze as positive and negative shock, whether the shock grater or lower than initial values as below:

$\grave{o}_{j i}^{+}=\max \left(\grave{o}_{j i}, 0\right)$ and $\grave{o}_{j i}^{-}=\min \left(\grave{o}_{j i}, 0\right)$

And such that

$X_{j, t}=X_{j, t-1}+\grave{o}_{j, t}=X_{j, 0}+\sum_{i=1}^{t} \grave{o}_{j i}^{+}+\sum_{i=1}^{t} \grave{o}_{j i}^{-}$ accumulated:

These negative and positive shocks can be $X_{j, t}^{+}=\sum_{i=1}^{t} \grave{o}_{j i}^{+}$and $X_{j, t}^{-}=\sum_{i=1}^{t} \grave{o}_{j i}^{-}$

We test asymmetric causality in time domain by employing vector autoregressive (VAR) model using Schwarz information criteria (SIC) optimal lag length. After selection of optimal lags, we run Wald test capture causality under the VAR model. VAR model specified as below:

$X_{k}^{t}=c+B_{1} X_{t-1}^{k}+B_{2} X_{t-2}^{k}+\ldots B_{L} X_{t-l}^{k}+V_{t}^{k}$
Where $\mathrm{k}$ is the type of component $X_{k}^{t}$ i.e. negative, positive or initial values of the time series data, and $B_{i}$ is the matrix of parameters. The simplified VAR model as below:

$\mathrm{X}=\mathrm{DZ}+\delta$

The null hypothesis of no causality, thus are tested as in the following form:

Wald $=(\mathrm{R} \beta)^{\prime}\left[R\left(\left(Z^{\prime} Z\right)^{-1} \mathrm{n} S\right) R^{\prime}\right]^{-1}(R \beta)$

Where $\mathrm{R}$ is shown as matrix of parameters, $\beta$ represent for column, $\mathrm{S}$ is variance matrix of unrestricted model and $\otimes$ is Kronecker. There is an issue in Wald test when heteroscedasticity $(\mathrm{ARCH})$ exist and normality is rejected, that's why bootstrapping is necessary.

\section{HYPOTHESIS}

Our study is based on below hypothesis which are:

Ho There is no influence of maize production on agriculture gross domestic product.

H1 There is influence of maize production on 
agriculture gross domestic product.

Ho There is no influence of rice production on agriculture gross domestic product.

$\mathrm{H} 1 \mathrm{There}$ is influence of rice production on agriculture gross domestic product.

Ho There is no influence of wheat production on agriculture gross domestic product.

H1 There is influence of wheat production on agriculture gross domestic product.

\section{RESULTS AND DISCUSSION}

Before starting the interpretation of result first we explain the descriptive statistics of dependent and independent variables and also included the unit root test results however, in the next step we will show the result and interpretation of asymmetric cointegration NARDL model (SHAHBAZ et al., 2017; SHIN YU et al., 2014).

Table 1 reveal the descriptive statistics of dependent and all independent variables. Agriculture GDP minimum, maximum and standard deviation values are $2981.334 \$, 73133.29 \$$ and $18294.24 \$$ respectively while, figure 3 shows upward movement trend in time series data. Wheat production's standard deviation and mean values in thousand tons 2263804 and 6362045 respectively while the graph indicates upward movement trend from 1970 to 2017 in figure 2 . The mean values of Rice and Maize in thousand tons are 6362045 and 2038802 respectively while the standard deviation values for both variable are 2263804 and 1531350. Figure 1 indicates the both crops production line graph which show constantly upward trend from the beginning to end and its mean the government policy and farmers trying to improve the per acre production.

Table 2 shows the results of Phillips-Perron (PP) (PHILLIPS \& PERRON, 1988) and Augmented Dickey Fuller (ADF) (DICKEY \& FULLER, 1979) test. These test find out the stationary of time series data that at how much level data are stationary if the results show that stationary level at first difference it will be allowed for co-integration and NARDL model. Results obtained from the ADF and PP test that all variables are stationary at first difference level I(1). Whereas all variables are stationary at $1^{\text {st }}$ difference further test and hypothesis could be perform.

\section{CO-INTEGRATION RESULTS}

In this section we explained the values of maize, rice and wheat production $79.5 \% \mathrm{R}^{2}=$ (0.7950) with Agriculture GDP. However the maize production, rice production and wheat production explained $79.5 \%$ of AGDP while the error value is here in the model showed the remaining variance in AGDP (20.5\%) growth. The result of DW test value is 1.6504 which mean auto-correlation is not present in the model. If the auto-correlation is not available in variables it could be the cause of growth in agriculture value added GDP and also there is no presence of white heteroscedasticity and serial correlation in the model. Due to Ramsay test the production function is sound and fit. The WD is very important for long and short run asymmetry where we could use for nonlinearity and asymmetry which is important when model are performing the relationship between the maize, rice and wheat production with Agriculture value added GDP variable. Further results in detail are showed below.

\section{Long run relationship of variables with $A G D P$}

In this section we discussed the long run relationship of variables with agriculture value added to GDP. The occurrence of positive shocks in maize production showed have positive and significant influence on AGDP while the coefficient value is 0.4195 the study is in line with (SIXTUS, 2010). The enhancement of maize production in country because $60 \%$ above of total population people are living in

Table 1 - Descriptive Statistic of Dependent and Independent Variables.

\begin{tabular}{lcccc}
\hline Variable & Mean & Std. Dev. & Min & Max \\
\hline AGDP & 22298.08 & 18294.24 & 2981.334 & 73133.29 \\
Rice & 6362045 & 2263804 & 3298400 & $1.12 \mathrm{e}+07$ \\
Maize & 2038802 & 1531350 & 705100 & 6134000 \\
Wheat & 6362045 & 2263804 & 3298400 & $1.12 \mathrm{e}+07$ \\
\hline
\end{tabular}

Source: Calculated by Author. 
Table 2 - Unit root test Trend and Intercept.

\begin{tabular}{|c|c|c|c|}
\hline Variables & Levels & $\mathrm{ADF}$ & PP \\
\hline \multirow{2}{*}{$\mathrm{Y}$} & Level & -2.3611 & -2.6021 \\
\hline & $1^{\text {st }}$ Difference & $-5.7110^{* * *}$ & $-5.6419^{* * *}$ \\
\hline \multirow{2}{*}{$\mathrm{R}$} & Level & $-4.4492^{* * *}$ & $-4.5114^{* * *}$ \\
\hline & $1^{\text {st }}$ Difference & $-10.0696^{* * *}$ & $-14.0348^{* * *}$ \\
\hline \multirow{2}{*}{ W } & Level & $-3.7235^{* *}$ & $-3.8335^{* *}$ \\
\hline & $1^{\text {st }}$ Difference & $-9.3213^{* * *}$ & $-20.3249^{* * *}$ \\
\hline \multirow{2}{*}{ M } & Level & -1.744 & $-20.3249^{* * *}$ \\
\hline & $1^{\text {st }}$ Differnce & $-7.3106^{* * *}$ & $-7.3106^{* * *}$ \\
\hline
\end{tabular}

Note: Symbol reveals statistical significance. ${ }^{* * *} 1 \%$ level, ${ }^{* *} 5 \%$ level and ${ }^{*} 10 \%$ level.

rural area and their livelihood directly and indirectly connect to agriculture. It is documented that maize had positive relationship with AGDP (REHMAN ET AL., 2016). The maize negative shocks coefficient value is (-4.3870) which has highly negative significant influence $10 \%$ level on AGDP. It is clear cut identified when maize production decreased automatically the agriculture gross domestic product could be decrease. It is warning to the policy maker of agriculture sector to be ready for this negative shocks if it occurs in future.

The positive shocks and negative shocks coefficient values of rice production are $(0.2778)$ and $(0.5556)$ which have positive and significant influence at $1 \%$ and $5 \%$ on AGDP. These results concluded that the positive and negative shocks to rice production play a key role in the long run on agriculture GDP. The area for rice production is increased because the government provided subsidies in inputs and as well as the highly demand at domestic level and due high consumption while Pakistani rice is very famous all over the world (GOP, 2018). Wheat production has positive impact on agriculture gross domestic product. Positive shocks in long run to wheat production has positive and highly significant effect the AGDP as well as negative shocks has positive and significant impact. The coefficient value of wheat production for positive shocks and negative shocks are 0.8145 and 1.4024 respectively. It is reported that wheat production has positive relationship with AGDP for long term (REHMAN ET AL., 2016). The increase in production quantity is totally depend upon the inputs such as fertilizer, machinery, seed and water availability if the agriculture administration focus on these input at suitable rate and provide on timely bases in future then agriculture sector and in future the country GDP could be increase.

\section{Short run relationship of variables with AGDP}

In this section it is explained that the short run relationship of independent variables with dependent variable. A positive shocks in maize production has positive and significant impact on agriculture gross domestic product. The maize coefficient value in short run is 0.4257 and while the probability value is 0.0169 . The negative shocks in short run of maize production has negative significant influence on AGDP of Pakistan. However the coefficient and probability values are -1.5589 and 0.0176 respectively. While the negative shock in maize production at (lag 1) has positive and significant at $10 \%$ influence on AGDP with coefficient value is 2.7142 and the study is line with (ANYANWU, 2010). It is concluded that the government did not focus to farmers and did not provide subsidies in inputs and credit scheme at low interest rateso that is why low production occurred in the short run while Pakistan agriculture sector is profitable sectors. The rice production with the occurrence of negative shock at (lag 1) has negative impact on agriculture GDP growth. It is revealed that positive shocks of wheat production in short run has positive and significant effect on AGDP growth at $10 \%$ level. It is indicated that the wheat production efficiency is good that is why production has positive effect on agriculture gross domestic. The negative shocks in wheat production at (lag 1) has negative significant at $5 \%$ at level influence on AGDP.

Pakistan agriculture sector have a lot of problems such as water availability, undeveloped infrastructure, poor policy of agriculture system and increasing the input price (CHANDIO \& JIANG, 2018). The agriculture policy makers need to design a long term and short term plans for the improvement of country agriculture system and specially target the famers benefit because half of the total Pakistan 
population is living in rural area and these people directly and indirectly connect with agriculture sector (GOP, 2017) (Table 3).

\section{Asymmetric causality among dependent and independent variables}

In this section we interpreted the results of symmetric and symmetric causal relationship of independent variables and dependent variable with Agriculture gross domestic product. From table 4 it is concluded the positive shocks in rice production did not have positive effect on AGDP while it is considered neutral impact. However there is no relationship between rice and AGDP thus the null hypothesis is accepted in asymmetric causality. The negative shocks in rice production has neutral effect on agriculture GDP and there is no granger causality relationship between these two variables. However the positive shocks in agriculture GDP has neutral effect on rice production while this asymmetric causality have not bidirectional and unidirectional effect. The above three relationships are show the null hypothesis acceptance. But the negative shock in AGDP growth has caused positive and significant influence on rice production which show unidirectional effect in the presence of symmetric causality.

The positive and negative shocks in rice production has neutral effect on AGDP growth and while there is no granger causalities relationship is found and automatically the null hypothesis is accepted for these two relationship. It is revealed that the positive and negative shocks in AGDP have neutral effect with rice production. In this case null hypothesis is accepted between the variables in asymmetric causality. The unidirectional and null hypothesis reject is found in the positive shock of wheat production to AGDP growth. It is reported that wheat production positive shock has granger causality and positive significant influence on AGDP growth. The wheat negative shock value 1.8964 has neutral effect with agriculture growth and while null hypothesis is accepted. It is indicated that positive shock P-value is 0.4404 of AGDP has granger causal relationship with wheat production. In the last of table 4 the results of AGDP P-value is 0.0243 has positive significant granger causal relationship with wheat production this relationship is unidirectional between these two variables.

\section{Symmetric Causality among dependent and} independent variables

In table 5 the long run shocks of rice production $\mathrm{P}$-value is 0.1683 has neutral effect on agriculture GDP while the null hypothesis is accepted. The government should provide a subsidies in input, facilitate the rice farmers where they problems. In long run the maize production test value is 0.0015 which has unidirectional

Table 3 - Co-integration Result.

\begin{tabular}{lccc}
\hline Variables & Co-efficient & T-Statistic & Probability \\
\hline Constant & $8.8779^{* * *}$ & 9.1773 & 0.0000 \\
\hline$Y_{t}$ & $-1.0770^{* * *}$ & -9.1536 & 0.0000 \\
\hline$M_{t}^{+}$ & $0.4195^{* * *}$ & 4.0340 & 0.0003 \\
$M_{t}^{-}$ & $-4.3870^{* * *}$ & -6.9228 & -6.9228 \\
$R_{t}^{+}$ & $0.2778^{*}$ & 1.9928 & 0.0551 \\
$R_{t}^{-}$ & $0.5556^{* *}$ & 2.6739 & 0.0119 \\
$R_{t}^{-}$ & $0.8145^{* * *}$ & 4.7151 & 0.0000 \\
$W_{t}^{+}$ & $1.4024^{* * *}$ & 3.5150 & 0.0014 \\
$W_{t}^{-}$ & $0.4189^{* * *}$ & 4.2008 & 0.0002 \\
$\Delta Y_{t-1}$ & $0.4257^{* *}$ & 2.5249 & 0.0169 \\
\hline$\Delta M_{t}^{+}$ & $-1.5589^{* *}$ & -2.5065 & 0.0176 \\
$\Delta R_{t-1}^{-}$ & $2.7142^{* * *}$ & 3.8567 & 0.0002 \\
$\Delta M_{t}^{-}$ & -0.2805 & -1.4503 & 0.1570 \\
$\Delta W_{t}^{-}$ & $1.1583^{* * *}$ & 3.2943 & 0.0025 \\
$\Delta W_{t-1}^{+}$ & $-0.5097^{* *}$ & 0.0025 & 0.0491 \\
\hline$R^{2}$ & 0.7950 & Adj $-\mathrm{R}^{2}$ & 0.7024 \\
\hline $\mathrm{D} . \mathrm{W}$ & 1.6504 & & \\
\hline
\end{tabular}

Note: + and - sign indicates the positive and negative shocks respectively, Significant level are ${ }^{* * *} 1,{ }^{* *} 5$ and ${ }^{*} 10$.

Ciência Rural, v.50, n.5, 2020. 
Table 4 - Asymmetric Causality Test Analysis.

\begin{tabular}{lccc}
\hline Hypothesis & Test- Value & P-value & Decision \\
\hline$R^{+} \nRightarrow Y^{+}$ & 4.5942 & 0.2037 & Accept null \\
$R^{-} \nRightarrow Y^{-}$ & 0.9837 & 0.8052 & Accept null \\
$Y^{+} \nRightarrow R^{+}$ & 5.4511 & 0.1416 & Accept null \\
$Y^{-} \Rightarrow R^{-}$ & $8.1591^{* *}$ & 0.0428 & Reject null \\
$M^{+} \nRightarrow Y^{+}$ & 5.8049 & 0.0428 & Accept null \\
$M^{-} \nRightarrow Y^{-}$ & 0.4082 & 0.9385 & Accept null \\
$Y^{-} \nRightarrow M^{-}$ & 3.8459 & 0.2786 & Accept null \\
$Y^{-} \nRightarrow M^{-}$ & 1.4184 & 0.7012 & Accept null \\
$W^{+} \Rightarrow Y^{+}$ & $8.3534^{* *}$ & 0.0392 & Reject null \\
$W^{-} \nRightarrow Y^{-}$ & 1.8964 & 0.5942 & Accept null \\
$Y^{+} \nRightarrow W^{+}$ & 2.6989 & 0.4404 & Accept null \\
$Y^{-} \Rightarrow W^{-}$ & $9.4112^{* *}$ & 0.0243 & Reject null \\
\hline
\end{tabular}

Note: $\Rightarrow$ and $\nRightarrow$ represent the directional and neutral effect, Significant level are ${ }^{* * *} 1,{ }^{* *} 5$ and ${ }^{*} 10$. (Asymmetric causality).

effect with agriculture gross domestic. It shows that maize production has influence in total AGDP for long time. The test value of agriculture GDP is (0.9553) which has symmetric causal relationship with maize production while the null hypothesis is accepted. Wheat production has not granger causality with AGDP while the null hypothesis is accepted and P-value is 0.6843 of AGDP. One big reason behind this result that demand for maize in household and industrial requirement is increased. The P-value of wheat production is 0.1807 has no directional relationship with agriculture added value to GDP. In the asymmetric causality relationship the alternate hypothesis rejected in this relationship.

The diagnostic test results are indicated in table 6. It is revealed that the results of residual Engle and Breusch Godfrey have not auto-correlation in the data. However the values of serial correlation and hetroscedasticity probability are 0.34 and 0.58 significant respectively. The values of Ramsay test and Wald test are suitable and correct while the probability values are 0.0046 and highly positively significant respectively. It is concluded from these test that all the data are normally distributed.

Figure 4 reveals the 5\% interval confidence plotted lines of cumulative sum and cumulative squares of model function. This graph show variables lines for the period 1970 to 2017 . Line cumulative sum and line for cumulative squares are steady because the both lines are traveling between 5\% confidence interval levels and while the results of model are reliable in present situation.

\section{CONCLUSION AND RECOMMENDATION}

By employing production function as a Non-linear Auto-Regressive Distributed Lag

Table 5 - Symmetric Causality Test Analysis.

\begin{tabular}{lccc}
\hline Hypothesis & Test- Value & P-value & Decision \\
\hline $\mathrm{R} \nRightarrow \mathrm{Y}$ & 5.0482 & 0.1683 & Accept null \\
$\mathrm{Y} \Rightarrow \mathrm{R}$ & $9.4607^{* *}$ & 0.0238 & Reject null \\
$\mathrm{M} \Rightarrow \mathrm{Y}$ & $15.422^{* * *}$ & 0.0015 & Reject null \\
$\mathrm{Y} \nRightarrow \mathrm{M}$ & 0.9553 & 0.8121 & Accept null \\
$\mathrm{W} \nRightarrow \mathrm{Y}$ & 4.8814 & 0.1807 & Accept null \\
$\mathrm{Y} \nRightarrow \mathrm{W}$ & 1.4913 & 0.6843 & Accept null \\
\hline
\end{tabular}

Note: $\Rightarrow$ and $\nRightarrow$ represent the directional and neutral effect, Significant level are ${ }^{* * *} 1,{ }^{* *} 5$ and ${ }^{*} 10$. (Asymmetric causality). 
Table 6 - Diagnostic Test.

\begin{tabular}{lccc}
\hline & ARCH test & Value & Probability \\
\hline$\chi^{2}-$ statistic & Serial Correlation & 2.1156 & 0.3472 \\
$\chi^{2}-$ statistic & Heteroscedasticity & 12.2042 & 0.5899 \\
F - statistic & Ramsey RESET test & 9.3737 & 0.0046 \\
F - statistic & Wald test & 12.6015 & 0.0000 \\
\hline
\end{tabular}

Source: computed by Author(s).

(NARDL), we examine the nexus between AGDP and rice, maize, wheat production 1 for time-series data from 1970 to 2017 in the case of Pakistan. We investigate the short-term long-term and equilibrium relationship. Our results reveal that a strong asymmetric co-integration relationship exists between the variables. Moreover, asymmetric causality is investigated for three cereal crops and AGDP.
If we just focus on symmetric result however, it would be very difficult to determine that negative shocks in wheat AGDP has negative influence on wheat production. But the positive shocks in Agriculture GDP do not have positive effect on wheat production. It is revealed from this result that negative shocks have negative effect, while the positive in Agriculture GDP do not positive effect. In this case

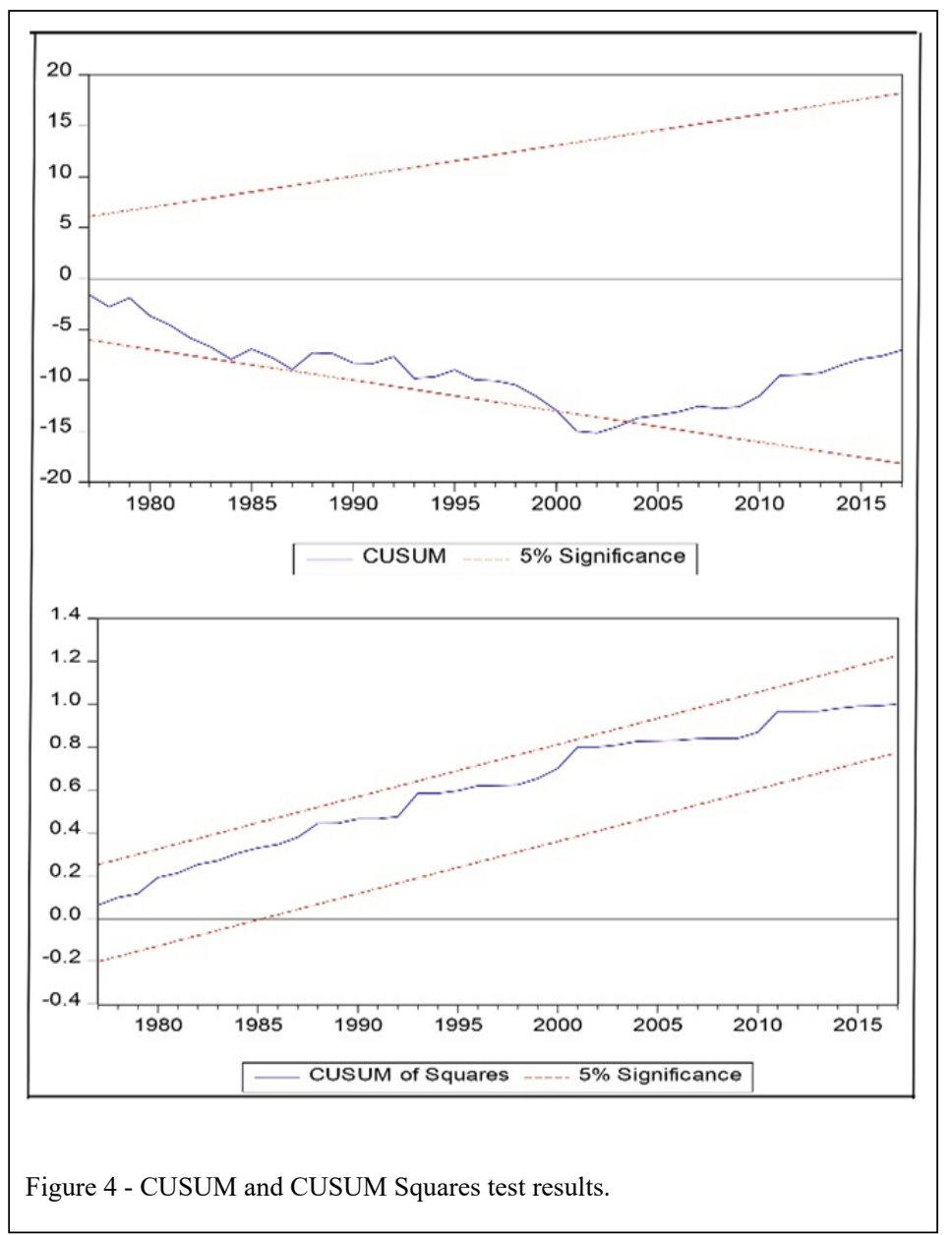

Ciência Rural, v.50, n.5, 2020. 
the Pakistan agriculture council should stable and maintain the wheat production according to domestic consumption and requirement for industries.

The relationship between rice production and AGDP growth, the outcome show in asymmetry is very important. Positive shocks in rice do not have positive and as well as the negative shocks in rice have the same result. This result proved that rice production positive and negative shocks do not have put contribution in the agriculture AGDP so the policy maker should focus the important policy of rice and provide subsidies in inputs. Conversely, regarding maize production, a unidirectional symmetric causal relationship is found with Agriculture GDP, which mean that maize crop is playing a key role for attaining long run agriculture gross domestic product growth. For maintainable AGDP growth, we recommend that the Pakistan agriculture council invest money for better agriculture system. Moreover, the policy makers should expand the maize production by putting more subsidies into input for maize.

Therefore, policy makers, researchers and government personnel should focus on cereal crops in Pakistan. Second, in the case of NARDL model, it is recommended that crops production have a robust long-run and short term relationship with agricultural GDP of Pakistan. Consequently, it needs more attention to maintain the long-run and short term relationship in future. In conclusion, this study recommends that to boost export of the country, the government of Pakistan should launch new projects for the development of the agricultural sector in general and in the horticulture sector in particular.

\section{ACKNOWLEDGMENTS}

This research was sponsored by a major project supported by National Natural Social Science Foundation of China (No. 71573211)

\section{CONTRIBUTIONS' AUTHORS}

IA and $\mathrm{XH}$ conceived and designed the research. $\mathrm{AK}$ and $\mathrm{KB}$ performed the data collection, analyzed the data and prepared the draft of the manuscript. HA, IK, QZ, and IA performed the proofread, edit, revised and approved the final version of manuscript collectively.

\section{DECLARATION OF CONFLICT OF INTERESTS}

The authors declared no potential conflicts of interest with respect to the research, authorship, and/or publication of this article.

\section{REFERENCES}

ALI, S et al. Climate change and its impact on the yield of major food crops: Evidence from Pakistan. Foods, v.6(6), p.39, 2017. Available from: <https://www.mdpi.com/2304-8158/6/6/39>. Accessed: Dec. 19, 2018. doi: 10.3390/foods6060039.

ANYANWU, S. et al. Agriculture share of the gross domestic product and its implications for rural development. v 2(8) p 26-31 2010. Report and Opinion, 2010. (ISSN: 1553-9873). Available from: $\quad<$ https://www.researchgate.net/publication/283301798>. Accessed: Dec. 15, 2018.

ATIF, R. M. et al. Pakistan's agricultural exports, determinants and its potential: an application of stochastic frontier gravity model. The Journal of International Trade \& Economic Development, v.26(3), p.257-276, 2017. Available from: <https:// www.researchgate.net/publication/309303574>. Accessed: Dec. 19, 2018. doi: 10.1080/09638199.2016.1243724

ARIF ULLAH et al. Testing long-run relationship between agricultural gross domestic product and fruits production: evidence from Pakistan. Ciência Rural, v.48:05, e20170854. 2018. Available from: <http://www.scielo.br/pdf/cr/v48n5/16784596-cr-48-05-e20170854.pdf>. Accessed: Dec. 19, 2018. doi: $10.1590 / 0103-8478 \mathrm{cr} 20170854$

BREITUNG, J; CANDELON, B. Testing for short-and longrun causality: A frequency-domain approach. Journal of econometrics, v.132 (2), p.363-378, 2006. Available from $<\mathrm{https}$ :// www.sciencedirect.com/science/article/pii/S030440760500059X $>$. Accessed: Dec. 19, 2018. doi: 10.1016/j.jeconom.2005.02.004.

DICKEY, D. A; FULLER, W. A. Distribution of the estimators for autoregressive time series with a unit root. Journal of the American statistical association, v.74(366a), p.427-431, 1997. Available from: <https://www.researchgate.net/publication/312992058>. Accessed: Dec. 19, 2018. doi: 10.2307/2286348.

DOROSH, P. A. Trade Liberalization and National Food Security: Rice Trade between Bangladesh and India. World development, 29(4), p.673-689, 2004. Available from: <https:// www.researchgate.net/publication/222298786>. Accessed: Dec. 19, 2018. doi: 10.1016/S0305-750X (00)00121-2.

FAOSTATE, 2018a. Food and Agriculture Organization (2018). FAO Statistic for 2018 , food agriculture statistic report for the year. Available from: <http://www.fao.org/faostat/en/\#data $>$. Accessed: Dec. 19, 2018.

FAOSTATE, 2018b. Food and Agriculture Organization of the United Nation, 2017-18. Available from: <http://www.fao.org/ economic/est/international-trade/en/>. Accessed: Dec. 12, 2018.

GOP- Government of Pakistan (2018). Government of Pakistan. Economic survey of Pakistan 2017-2018. Finance Division. Economic Adviser's Wing, Islamabad, 2017. Available from: $<$ http://www.finance.gov.pk/>. Accessed: Dec. 22, 2018.

GOP. Government of Pakistan (2017). Pakistan Bureau of Statistics. Available from: <http://www.pbs.gov.pk/content/ agriculture-statistics $>$. Accessed: Dec. 22, 2018. Islamabad Pakistan: 44000.

HATEMI-J, A. Asymmetric causality tests with an application. Empirical Economics, v.43(1), p.447-456, 2012. Available from: 
$<$ https://ideas.repec.org/a/spr/empeco/v43y2012i1p447-456. html/>. Accessed: Dec. 19, 2018. doi: 10.1007/s00181-011-0484-x.

HUSSAIN, A. H. Impact of credit disbursement, area under cultivation, fertilizer consumption and water availability on rice production in Pakistan (1988-2010). Sarhad Journalof Agriculture, v.28, No.1, 2012. Available from: <https://mpra. ub.uni-muenchen.de/41963/1/MPRA_paper_41963.pdf $>$. Accessed: Dec. 19, 2018. doi: 10.1088/2041-8205/808/2/L49.

IOHNSTON, B. F. (1970). Agriculture and structural transformation in developing countries: a survey of research. Journal of Economic Literature, v.8(2), p.369-404, 1970. Available from: $<$ https://www. researchgate.net/publication/4725103>. Accessed: Dec. 19, 2018.

MAPFUMO, A. An econometric analysis of the relationship between agricultural production and economic growth in Zimbabwe. Russian Journal of Agricultural and SocioEconomic Sciences, v.11, p.23, 2013. Available from: $<\mathrm{https}$ :// www.researchgate.net/publication/289509538>. Accessed: Dec. 19, 2018. doi: 10.1007/978-94-007-7636-4_5.

PHILlIPS, P. C; PERRON, P. Testing for a unit root in time series regression. January 1986. Biometrika, v.75, (795R) 1988. Available from: <https://www.researchgate.net/ publication/4744135>. Accessed: Dec. 19, 2018. doi: 10.1093/ biomet/75.2.335.

RANUM, $\mathrm{P}$ et al. Global maize production, utilization, and consumption. Analysis of the New York academy of sciences, v.1312(1), p.105-112, 2014. Available from: <https://www. researchgate.net/publication/260995060>. Accessed: Dec. 19, 2018. doi: $10.1111 /$ nyas. 12396 .

RAZA, S. A. Role of agriculture in economic growth of Pakistan International Research Journal of Finance and Economics. Euro Journals Publishing, Incorporation. 2012 ISSN 1450-2887 Issue v.83 (2012). Available from: <https://www.researchgate.net/ publication/228518268>. Accessed: Dec. 19, 2018.

REHMAN, A et al. Economic perspectives of major field crops of Pakistan: An empirical study. Pacific Science Review B Humanities \& Social Sciences, v.2(1), p.6-35, 2016. Available from: <https:// www.sciencedirect.com/science/article/pii/S2405883116300569>. Accessed: Dec. 19, 2018. doi: 10.1016/j.psrb.2016.09.002.
SARWAR, M. H. The importance of cereals (Poaceae: Gramineae) nutrition in human health: A review. Journal of cereals and oilseeds, v.4(3), p.32-35, 2013. Available from: <https:/ academicjournals.org/journal/JCO/articleabstract/CECB450571>. Accessed: Dec. 19, 2018. doi: 10.5897/JCO12.023.

SECK, P. A et al. Crops that feed the world 7: rice. Food Security, v.4(1), p.7-24, 2012. Available from: <https://www.researchgate. net/publication/257788764>. Accessed: Dec. 19, 2018. doi: 10.1007/s12571-012-0168-1.

SHAHBAZ, M. et al. Energy Consumption, Financial Development and Economic Growth in India: New Evidence from a Nonlinear and Asymmetric Analysis. Energy Economics, v.66, 199 p.212, 2017. Available from: <https://www.sciencedirect.com/science/ article/pii/S0140988317300336>. Accessed: Dec. 19, 2018. doi: 10.1016/j.eneco.2017.01.023.

SHIN, Y et al. Modelling Asymmetric Co-integration and Dynamic Multipliers in a Nonlinear ARDL Framework. Social Science Electronic Publishing, p.281-314, 2013. Available from: $<\mathrm{https}$ :// www.researchgate.net/publication/228275564>. Accessed: Dec. 19, 2018. doi: 10.2139/ssrn.1807745.

SINGH, T. On the sectoral linkages and pattern of economic growth in India. Journal of the Asia Pacific Economy, v.21(2), p.1-19, 2016. Available from: <https://www.researchgate. net/publication/283848175>. Accessed: Dec. 19, 2018. doi: 10.1080/13547860.2015.1094175.

SIXTUS, A. (2010). Agriculture Share of the Gross Domestic Product and its Implications for Rural Development. World Rural Observations. v.2(3), p.1-5, 2010. ISSN: 1944-6543 (Print). Available from: <https://www.researchgate.net/ publication/283301798>. Accessed: Dec. 19, 2018.

USDA- UNITED STATES DEPARTMENT OF AGRICULTURE (2017). USDA Foreign Agriculture Services, Available from: $<$ https://www.researchgate.net/publication/332370154_United_ States_Department_of_Agriculture>.Accessed: Dec. 19, 2018.

WDI-WORLD DEVELOPMENT INDCATOR (2017-18). World Bank Publications, Washington, DC. Available from: $<$ https://databank.worldbank.org/reports.aspx? source=worlddevelopment-indicators $>$. Accessed: Dec. 19, 2018. 